\title{
PENGARUH PENGUASAAN MATERI MATEMATIKA DANPENGETAHUAN EVALUASI TERHADAP KUALITAS TES MATEMATIKA BUATAN GURU 2013
}

\author{
Asep Irwansyah ${ }^{1}$ \\ ${ }^{1}$ Program studi PG- PAUD, Fakultas Ilmu Pendidikan Universitas MH. Thamrin
}

\begin{abstract}
ABSTRAK
Dalam proses pembelajaran, seorang guru pada prinsipnya dapat menggunakan alat testing buatan guru itu sendiri atau testing baku. Alat testing baku pada umumnya difokuskan untuk melengkapi butir-butir acuan normatif, berisi daftar skor sejenis yang diambil dari sampel siswa yang diasumsikan merepresentasikan populasi dimana tes direncanakan dapat digunakan. Sedangkan alat testing buatan sendiri digunakan jika guru ingin memperoleh informasi yang unik dan spesifik tentang para siswa. Namun pada umumnya tes buatan guru, baik tes formatif maupun sumatif belum dianalisis tingkat validitasnya, reliabilitas, daya beda dan tingkat kesukarannya. Sehingga tidak beralasan untuk mengatakan bahwa tes tersebut berkualitas atau tidak, meskipun telah diisusun berdasarkan pokok bahasan yang telah diajarkan dan tujuan intruksional yang telah ditetapkan. Guru sebagai dasar untuk memperbaiki proses belajar mengajar, dan sebagai dasar untuk memperbaiki program siswa pengukuran dan penilaian yang diberikan setelah selesai mengajar suatu satuan pelajaran akan dapat memberi informasi tentang kekurangan-kekurangan atau kesalahan yang ada, hingga guru dapat mengadakan perbaikan setepat-tepatnya.
\end{abstract}

Kata Kunci: Kualitas soal, penguasaan materi, pengetahuan evaluasi

\section{Pendahuluan}

Pendidikan merupakan faktor utama dalam membangun masa depan bangsa. Dengan pendidikan diharapkan dapat mempersiapkan kader-kader pemimpin bangsa, pembangunan bangsa, dan pelopor kemajuan bangsa. Pendidikan di Indonesia telah di upayakan untuk menggali sumber daya manusia dengan meningkatkan komponen-komponen pendidikan, baik dari segi manusianya yaitu pelaku pendidikan dan dari segi perangkat pendidikan.

Menghadapi pesatnya perkembangan ilmu dan teknologi dewasa ini serta tuntutan terhadap peningkatan kualitas sumber daya manusia dalam menghadapi persaingan global, telah menempatkan sektor pendidikan pada posisi yang sangat menentukan. Berbicara mengenai sektor pendidikan akan melibatkan banyak unsur seperti guru, siswa, pemerintah,masyarakat dan faktor penunjang lainnya. Dari sekian banyak faktor yang berperan serta dalam kemajuan pendidikan, semuanya saling keterkaitan satu dengan yang lain. Akan tetapi faktor guru merupakan sesuatu yang bisa dikatakan sangat penting sekali. Guru dapat dikatakan seorang sutradara yang dapat mengarahkan situasi dan kondisi yang bagaimanapun untuk mencapai tujuan.

Guru dalam konteks pendidikan mempunyai peranan yang besar dan strategis. Hal ini gurulah yang berada dibarisan terdepan berhadapan dengan peserta didik untuk mentransfer ilmu pengetahuan dan teknologi sekaligus mendidik dengan nilai - nilai positif melalui bimbingan dan keteladanan.

Guru sebagai pendidik mempunyai tanggung jawab secara formal (kepada atasan yang mengangkatnya) dan secara moral (kepada sasaran didik dan Tuhan Yang Maha Esa). Karena itu, guru dituntut menyelenggarakan proses pendidikan dengan penuh pemahaman dan penghargaan terhadap anak didiknya. Seorang guru tidak cukup memahami karakteristik siswa sebagai subjek didik atau peserta didik tetapi lebih jauh seorang guru dituntut untuk memahami karakteristik pribadi dirinya dan kondisi serta situasi pendidikan.

Kekuatan dan mutu pendidikan suatu Negara dapat dinilai dengan faktor guru sebagai salah satu indeks utama. Itulah sebabnya mengapa guru merupakan faktor yang mutlak di dalam pembangunan. Makin bersungguh-sungguh sebuah pemerintahan untuk membangun negaranya maka menjadi urgen kedudukan guru.

Guru sebagai pelaksana pendidik memegang peranan penting, guru sangat menentukan keberhasilan pendidikan. Gurulah yang berinteraksi langsung dengan siswa-siswinya. Indikasi keberhasilan guru dan siswa dalam mencapai tujuan program pembelajaran akan dapat diketahui melalui informasi yang didapat dari proses penilaian.

Guru adalah pendidik professional dengan tugas utama mendidik, mengajar, membimbing, mengarahkan, melatih, menilai dan mengevaluasi peserta didik pada pendidikan anak usia dini dan menengah. Guru berperan sebagai mediator dan fasilitator. Maksud dari pernyataan ini adalah bahwa guru merupakan sosok manusia yang memiliki pengetahuan dan pemahaman yang cukup. Sebagai mediator seorang guru dituntut untuk mampu mengkomunikasikan materi pembelajaran baik dalam rangka perubahan tingkah laku siswa maupun dalam rangka pengubahan keterampilannya. Adapun sebagai fasilitator seorang guru dituntut untuk selalu menyiapkan segala keperluan pembelajaran baik untuk siswanya maupun untuk dirinya. 
Selanjutnya, sangat berpengaruh kepada kepercayaan yang akan diberikan pada guru untuk tugasnya dalam mendidik sebagai pendidik dalam kesehariannya guru dituntut untuk selalu memiliki kesadaran diri akan profesi yang akan diamanahkan. Sosok pribadi guru harus dapat menjadi teladan bagi anak didik dan lingkungannya. Perilaku mereka akan menjadi sorotan masyarakat, sedikit saja cacat dalam berprilaku akan menjadi besar yang dapat mencoreng citra kependidikan secara luas. Citra diri berkaitan dengan karakter dan kepribadian guru. Berbagai studi menunjukan bahwa guru dapat mempengaruhi perilaku anak dengan lebih efektif.

Fungsi guru yang dapat menangani proses belajar dikelas sangat strategis dalam upaya meningkatkan adab stabilitas managemen sekolah terutama kaitannya dalam proses belajar siswa. Guru yang berfungsi sebagai tenaga pengalih pengetahuan serta keterampilan, sudah seharusnya secara berkesinambungan berusaha mengembangkan kemampuan profesionalnya, dapat menyesuaikan diri terhadap tuntutan masyarakat. Karena itu peningkatan pengetahuan professional guru tidak bisa ditawar-tawar lagi dalam upaya meningkatkan sumber daya manusia. Guru memiiki peran yang penting, merupakan posisi strategis dan bertanggungjawab dalam pendidikan nasional. Guru memiliki tugas sebagai pendidik, pengajar dan pelatih.

Guru perlu menguasai berbagai hal sebagai kompetensi yang dimiliki. Disisi lain, guru harus memahami dan menghayati para siswa yang dibinanya sebab keterampilan guru mengajar merupakan faktor kunci yang menjamin meningkatnya kualitas tes. Tetapi dalam kenyataan terdapat indikasi bahwa kualitas tes buatan guru masih rendah.

Tes buatan guru, baik tes formatif maupun sumatif belum dianalisis tingkat validitas, reliabilitas, daya beda, dan tingkat kesukaran. Sehingga tidak beralasan untuk mengatakan bahwa tes tersebut berkualitas atau tidak, meskipun telah disusun berdasarkan pokok bahasan yang telah diajarkan dan tujuan intruksional yang telah ditetapkan.

Rendahnya kualitas tes buatan guru dapat disebabkan oleh rendahnya pengetetahuan evaluasi dan penguasaan guru terhadap materi, tidak dapat diragukan bahwa untuk mengembangkan sekolah diperlukan pembuatan tes yang berkualitas. Namun demikian, beberapa pakar menyadari bahwa kualitas tes khususnya tes buatan guru di sekolah pada umumnya rendah.

Guru dihadapkan kepada keharusan untuk mengambil keputusan tentang manusia atau untuk menolong seseorang mengambil keputusan tentang dirinya sendiri. Keputusan tidak dapat diambil tanpa pengetahuan yang cukup tentang hal yang akan diputuskan itu. Pengukuran dan penilaian yang dapat memberikan informasi yang guru perlukan, sehingga dimungkinkan dalam pengambilan keputusan.

Dalam bidang pendidikan, pengukuran memegang peranan yang sangat penting. Data hasil pengukuran dalam bidang pendidikan memiliki arti penting bagi sekolah atau lembaga pendidikan, guru, maupun bagi siswa dan orang tua siswa atau masyarakat. Bagi guru misalnya hasil pengukuran berfungsi untuk membandingkan tingkat kemampuan siswa dengan siswa - siswa lain dalam kelompok yang diajarnya.

Di sekolah penilaian atau evaluasi mempunyai perana penting. Guru harus mengenal siswanya dengan baik, sehingga dapat mengambil keputusan dengan tepat setiap kali diperlukan. Evaluasi dan pengukuran sangat erat berhubungan, evaluasi tidak dapat dilakukan tanpa didahului dengan pengukuran. Dalam pengukuran orang membandingkan sesuatu dengan ukuran atau normal yang sudah dibakukan. Setelah dilakukan pengukuran kemudian dilakukan penilaian.

Pengukuran (measurement) yang dilakukan untuk mengukur dalam arti memberi angka terhadap sesuatu yang disebut obyek pengukuran atau obyek ukur. Pengukuran memegang peranan yang sangat penting, data hasil pengukuran dalam bidang pendidikan memiliki arti penting baik bagi sekolah atau lembaga pendidikan, guru, maupun bagi siswa dan orang tua siswa dan masyarakat. Bagi guru hasil pengukuran berfungsi untuk membandingkan tingkat kemampuan siswa dengan siswa-siswa lainya.

Penilaian di sekolah dilakukan secara sistematis untuk mengumpulkan informasi tentang hasil belajar atau tingkat pencapaian siswa tentang materi yang sudah disampaikan guru. Untuk memperoleh data hasil belajar siswa, maka dilaksanakan pengukuran dengan menggunakan alat berupa tes. Data yang diperoleh diolah sehingga akan mendapatkan tafsiran gambaran prestasi belajar siswa secara menyeluruh dan komprehensif. Data tersebut akan dijadikan acuan untuk mengambil keputusan apakah siswa sudah menguasai materi yang disampaikan guru atau belum.

Penilaian kegiatan belajar mengajar perlu dilakukan dengan sebaik-baiknya, yaitu dengan menggunakan tes yang berkualitas baik dan standar. Untuk melaksanakan hal tersebut para guru perlu memiliki pengetahuan dan keterampilan dalam membuat soa-soal yang sesuai dengan kaidah penulisan soal.

Evaluasi yang berarti pengungkapan dan pengukuran hasil belajar, pada dasarnya merupakan proses penyusunan deskripsi siswa, baik secara kuantitatf maupun kualitatif. Namun sebagaimana yang terjadi kebanyakan pelaksanaan evaluasi cenderung masih bersifat kuantitatif. Hal ini terjadi karena penggunaan simbol angka dan skor untuk menentukan kualitas keseluruhan kinerja akademik siswa masih dianggap masih nisbi. Namun demikian, guru yang piawai dan profesional harus berusaha mencari cara-cara atau kiat evaluasi yang lugas, tuntas, dan karsa siswa guna mengurangi kenisbian hasilnya. 
Evaluasi bukan sekadar menilai suatu aktivitas secara spontan dan insendental, melainkan merupakan kegiatan untuk menilai sesuatu secara terencana, sistematik, dan terarah berdasarkan atas tujuan yang jelas. Evaluasi hasil belajar bertujuan untuk mengetahui hasil belajar atau pembentukan kompetensi peserta didik.

Setiap penilaian pasti ada tujuannya, penilaian yang dilakukan guru terhadap anak didiknya disekolah pada dasarnya bertujuan. Tujuan penilaian sebagai berikut: memberi umpan balik (Feed Back), mengetahui prestasi belajar siswa (Achievement), menempatkan siswa dalam situasi belajar mengajar yang tepat, mengenai latar belakang (Psikologis, fisik dan lingkungan).

Guru sebagai dasar untuk memperbaiki proses belajar mengajar, dan sebagai dasar untuk memperbaiki program siswa pengukuran dan penilaian yang diberikan setelah selesai mengajar suatu satuan pelajaran akan dapat memberi informasi tentang kekurangan-kekurangan atau kesalahan yang ada, hingga guru dapat mengadakan perbaikan setepattepatnya.

Angka-angka yang diperlukan untuk memberi laporan prestasi belajar siswa kepada orang tua, untuk menentukan kenaikan kelas, lulus tidaknya siswa dan untuk menentukan kedudukan atau rangking siswa dalam kelasnya.

Sesuai dengan kemampuan dan karakteristik siswa. Misalkan dalam pengelompokan siswa kedalam kelompok yang cepat belajar atau yang sedang-sedang saja kecepatan belajarnya. Pengelompokan itu setiap kali dapat berubah komposisinya sesuai dengan perkembangan (Placement dan Replacement). Siswa yang mengalami kesulitan belajar sehingga dapat menemukan sebab-sebab mengapa siswa sulit belajar (diagnostic).

\section{Kajian Literatur}

\section{Kualitas Tes Buatan Guru}

Arikunto (2009) berpendapat tes adalah Tes adalah suatu alat pengumpul informasi tetapi jika dibandingkan dengan alat-alat lain, tes bersifat resmi karena penuh dengan batasan- batasan. Tes dapat dikatakan pula alat atau prosedur yang digunakan untuk mengetahui atau mengukur sesuatu dalam suasana, dengan cara dan aturan-aturan yang sudah ditentukan.

Tes adalah alat yang digunakan untuk mengukur kemampuan siswa atau sesorang yang telah dipersiapkan berdasarkan tujuan-tujuan yang ingin dicapai. Artinya butir-butir tes disusun dengan cermat yaitu dengan aturan-aturan, pengadministrasian dilakukan dengan benar, serta pemberian dengan skor terhadap hasilnya harus jelas dan dispesifikasi secara rinci. Tes berisi sampel perilaku artinya tes dapat mewakili secara representatif seluruh aspek yang akan ukur, kelayakan tes tergantung pada sejauhmana butir soal didalam tes itu mewakili secara reprensentatif kawasan perilaku yang akan diukur, dan pertanyaan-pertanyaan atau butir-butir soal dalam tes mengukur apa yang diketahui dan dipelajari peserta tes.

Sebuah tes dapat dikatakan baik sebagai alat pengukur harus memenuhi persyaratan tes, syarat - syarat sebagai berikut: 1) Validitas, 2) Reliabillitas,

3.) Objektivitas, 4) Praktikabilitas (Practicability), 5) Ekonomis.

Alat evaluasi disekolah hampir semuanya dibuat oleh guru sendiri. Maka guru hendaknya berusaha menyusun tesnya dengan mencoba memenuhi syarat - syarat yang baik, menganalisanya sesudah memberikan kepada siswa - siswanya, dan memperbaikinya.

Alat yang digunakan untuk mengadakan evaluasi yaitu tes dan non tes. Tes merupakan alat pertama untuk mengukur dan menilai hasil belajar siswa yang beraspek kognitif dan psikomotorik. Informasi tentang seseorang dapat juga diperoleh dengan berbagai cara, teknik atau metode yang terdiri dari observasi atau pengamatan, wawancara, angket atau kuesioner, skala penilaian atau rating scale, surat rekomendasi atau letter of recommendation. Jenis tes yang digunakan disekolah untuk mengevaluasi kemampuan siswa antara lain tes tulis, tes lisan, dan tes buatan. Kualitas soal dapat kita ketahui dari : 1) validitas, 2) reliabilitas, 3) analisis butir soal yang meliputi :a) tingkat kesukaran butir soal, b) daya beda butir soal, c) keefektifan pengecoh.

Sudiono (1995) berpendapat tentang pengelompokan tes hasil belajar di klasifikasikan menjadi dua yaitu : Tes Baku dan Tes Buatan Guru. Tes baku adalah tes yang dipublikasikan dan yang telah dipersiapkan oleh para ahli secara cermat serta mencakup tujuan akademis yang lajim bagi sekolah-sekolah pada umumnya. Tes baku ini adalah tes-tes yang norma-norma perbandingannya telah diperoleh validitasnya dan reliabilitas telah ditetapkan, dan petunjuk pelaksanaan serta pemberian skornya telah ditentukan. Sedangkan tes buatan guru adalah tes yang dibuat sendiri oleh guru dan untuk lingkungan sendiri.

Tes baku, tes standar atau 'standarlized test', tes yang sudah dilakukan karena sudah memenuhi syarat tes yang baik. Tes baku sudah mengalami uji coba dan perbaikan berulang kali. Biasanya tes baku sudah dibuat oleh intitusi atau badan khusus yang bergerak dalam bidang penyusunan tes. Santosa Murwani ${ }^{1}$ mengemukakan tentang tes baku sebagai berikut : Tes baku selalu disertai buku pedoman ( manual ) berisi: 1) Cara penggunaannya, 2) Cara Menafsirkan hasil tes, 3) Struktur tes, 4) Validitas Tes, 5) Reliabilitas tes. 
Tes baku itu tes yang sudah dilakukan karena sudah memenuhi syarat - syarat tes yang baik. Tes baku sudah mengalami uji coba dan perbaikan berulang kali. Tes baku untuk mengukur hasil belajar siswa belum ada, maka guru di Indonesia membuat tes untuk siswanya yang disebut dengan tes buatan guru.

Pada intinya tes hasil belajar diklasifikasikan menjadi dua yaitu tes baku dan tes buatan guru. Arikunto (2009) berpendapat tentang tes baku dan tes buatan guru sebagai berikut :Tes baku adalah tes yang dipublikasikan dan telah disiapkan oleh para ahli secara cermat serta mencakup tujuan akademis yang lazim bagi sekolah - sekolah pada umumnya. Tes baku merupakan tes - tes yang norma - norma perbandingannya telah diperoleh validitas dan reliabilitas telah ditetapkan, dan petunjuk pelaksanaan serta pemberian skornya telah ditentukan. Sedangkan tes buatan guru adalah tes yang dibuat sendiri oleh guru dan untuk lingkungan sendiri.

Dalam proses pembelajaran, seorang guru pada prinsipnya dapat menggunakan alat testing buatan guru itu sendiri atau testing baku. Alat testing baku pada umumnya difokuskan untuk melengkapi butir-butir acuan normatif, berisi daftar skor sejenis yang diambil dari sampel siswa yang diasumsikan merepresentasikan populasi dimana tes direncanakan dapat digunakan. Sedangkan alat testing buatan sendiri digunakan jika guru ingin memperoleh informasi yang unik dan spesifik tentang para siswa.

Namun pada umumnya tes buatan guru, baik tes formatif maupun sumatif belum dianalisis tingkat validitasnya, reliabilitas, daya beda dan tingkat kesukarannya. Sehingga tidak beralasan untuk mengatakan bahwa tes tersebut berkualitas atau tidak, meskipun telah diisusun berdasarkan pokok bahasan yang telah diajarkan dan tujuan intruksional yang telah ditetapkan.

Oleh karena itu guru harus selalu beusaha memperbaiki tesnya supaya informasi tentang hasil belajar siswa menjadi lebih dapat dipercaya. Dengan menganalisis tiap-tiap jawaban siswa, guru dapat mengetahui kelemahan soal-soal itu, memperbaikinya, dan menyiapkan soal yang lebih baik untuk tes serupa yang akan datang.

Guru berusaha tampil dengan penampilan dan sikap yang baik, agar materi yang diajarkan dapat menarik siswa. Sebelum guru itu tampil didepan kelas mengelola interaksi belajar mengajar, terlebih dahulu harus sudah menguasai bahan apa yang akan disampaikan dan sekaligus bahan - bahan apa yang dapat mendukung jalanya proses belajar mengajar. Dengan modal menguasai bahan, maka guru akan dapat menyampaikan materi pelajaran secara dinamis, dalam hal ini yang dimaksud "menguasai bahan" bagi seorang guru adalah mencakup dua lingkup penguasaan materi. Sardiman (2000) berpendapat tentang lingkup penguasaan guru materi guru adalah sebagai berikut:1) Menguasai bahan bidang studi dalam kurikulum sekolah, 2) Menguasai bahan pengajaran atau bidang studi.

Suyanto (2000) berpendapat tentang seorang guru harus memiliki kompetensi professional yaitu sebagai berikut: "seorang guru harus menilai pengetahuan yang luas, mendalam dari bidang studi yang diajarkan".

Penguasaan materi pelajaran meliputi bidang studi dalam kurikulum sekolah atau madrasah, serta bahan pendalaman maupun aplikasi. Hal ini memungkinkan guru untuk menyajikan dengan sebaik - baiknya, dengan mengembangkan dan menyesuaikan konsep keilmuan dengan perkembangan jaman. ${ }^{2}$

Mengenai penguasaan materi, Purwanto(1980) berpendapat sebagai berikut : "seorang guru haruslah berpengetahuan luas, benar - benar menguasai mata pelajaranya, suka kepada mata pelajaranya yang diajarkan". Selain mempunyai pengetahuan yang dalam tentang bidang studi yang sudah menjadi tugasnya, akan lebih baik lagi jika guru itu mengetahui pula tentang segala sesuatu yang ada hubungannya dengan studi yang diajarkan.

Disamping menguasai materi sesuai yang tertera dalam kurikulum sekolah, guru juga dituntut untuk menguasai bahan pelajaran lain dapat memberikan pengajaran serta memperjelas bahan - bahan bidang studi yang dipegangnya, sehingga penyampaian materi dapat lebih efektif dan dinamis. Dengan demikian guru akan lebih mampu merumuskan tujuan intruksional yang tepat. Hal ini memberikan pengertian bahwa seorang guru matematika selain ia harus menguasai bidang studi matematika yang diajarnya ia juga harus mengetahui hubungan antara materi matemtika yang diajarkan dengan bidang studi lain seperi fisika, kimia, biologi, dan penerapan matematika dalam bidang sosial atau kehidupan sehari - hari.

Penguasaan materi guru terhadap bidang studi yang diajarkannya juga akam mempengaruhi kemampuan guru dalam hal perencanaan pengajaran, persiapan pelaksanaan pengajaran, kemudian juga kemampuan guru dalam merumuskan tujuan intruksional yang merupakan faktor penting dalam perumusan alat evaluasi atau item - item tes. Walujo ${ }^{3}$ berpendapat tentang penilaian senagai berikut : "dalam hal penilaian yang penting adalah penguasaan materi, bukan teknik membuat alat ukur, dan penilaian yang sesuai dalam hal yang diukur atau di evaluasi".

Nawawi ${ }^{4}$ berpendapat tentang guru sebagai berikut: "Guru adalah orang yang bekerja dalam bidang pendidikan dan pengejaran, yang ikut bertanggung jawab dalam membantu anak - anak dalam mencapai kedewasaan masing masing. 
Mulyasa ${ }^{5}$ berpendapat tentang guru sebagai berikut : "Guru merupakan sosok yang begitu dihormati lantaran memiliki andil yang sangat besar terhadap keberhasilan pembelajaran di sekolah". Guru sangat berperan dalam membantu perkembangan peserta didik untuk mewujudkan tujuan hidupnya secara optimal. Ketika orang tua mendaftarkan anaknya ke sekolah, pada saat itu juga ia menaruh harapan terhadap guru, agar anaknya dapat berkembang secara optimal.

Pengetahuan yang lebih menekankan pengamatan dan pengalaman inderawi dikenal sebagai pengetahuan empiris atau pengetahuan aposteriori. Pengetahuan ini bisa didapatkan dengan melakukan pengamatan dan observasi yang dilakukan secara empiris dan rasional. Pengetahuan empiris tersebut juga dapat berkembang menjadi pengetahuan deskriptif bila seseorang dapat melukiskan dan menggambarkan segala ciri, sifat, dan gejala yang ada pada objek empiris tersebut. Pengetahuan empiris juga bisa didapatkan melalui pengalaman pribadi manusia yang terjadi berulangkali. Misalnya, seseorang yang sering dipilih untuk memimpin organisasi dengan sendirinya akan mendapatkan pengetahuan tentang manajemen organisasi.

Selain pengetahuan empiris, ada pula pengetahuan yang didapatkan melalui akal budi yang kemudian dikenal sebagai rasionalisme. Rasionalisme lebih menekankan pengetahuan yang bersifat apriori; tidak menekankan pada pengalaman. Misalnya pengetahuan tentang matematika. Dalam matematika, hasil $1+1=2$ bukan didapatkan melalui pengalaman atau pengamatan empiris, melainkan melalui sebuah pemikiran logis akal budi.

Pengetahuan seseorang dipengaruhi oleh beberapa faktor, faktor - faktor diantaranya sebagai berikut:1) Pendidikan, 2) Media, 3) Keterpaparan informs. Menurut Wayan dan Sumantha (1986) mengemukakan definisi evaluasi adalah Evaluasi yang berarti pengungkapan dan pengukuran hasil belajar, pada dasarnya merupakan proses penyusunan deskripsi siswa, baik secara kuantitatf maupun kualitatif. Menurut Wand dan Brown yang dikutip Wayan dan Sumanta, evaluasi adalah suatu tindakan atau suatu proses untuk menentukan nilai daripada sesuatu. Evaluasi pendidikan dapat diartikan suatu tindakan atau proses untuk menentukan nilai segala sesuatu dalam dunia pendidikan atau segala sesuatu yang ada hubungannya dengan dunia pendidikan.

Evaluasi pendidkan dapat diartikan sebagai suatu tindakan atau suatu proses untuk menentukan nilai segala sesuatu dalam dunia pendidikan atau segala sesuatu yang ada hubungannya dengan dunia pendidikan.

Evaluasi dengan tujuan suatu kegiatan yang mengukur suatu derajat, dimana suatu tujuan dapat dicapai. Sebenarnya evaluasi juga merupakan proses memahami, memberi arti, mendapatkan, dan mengkomunikasikan suatu informasi bagi keperluan pengambil keputusan.

Kaitan antara evaluasi dan pengukuran sangat erat berhubungan, evaluasi tidak dapat dilakukan tanpa didahului dengan pengukuran. Dalam pengukuran orang membandingkan sesuatu dengan ukuran atau normal yang sudah dibakukan Setelah dilakukan pengukuran kemudian dilakukan penilaian.

Evaluasi adalah kesimpulan dari serangkaian pengukuran, sehingga diperoleh gambaran yang menyeluruh tentang siswa atau kelompok siswa. Dalam pengukuran orang membandingkan sesuatu dengan ukuran atau norma yang sudah dibakukan. Evaluasi dan pengukuran sangat erat hubungannya, evaluasi tidak dapat dilakukan tanpa didahului dengan pengukuran. Dalam mengukur hasil belajar siswa, guru sudah menentukan norma standar atau standar penilaian yang akan digunakan menjadi pembanding pada waktu memeriksa hasil tes siswa.

Evaluasi pembelajaran merupakan inti bahasan evaluasi yang kegiatannya dalam lingkup kelas atau dalam proses belajar mengajar. Evaluasi pembelajaran kegiatannya termasuk kegiatan evaluasi yang dilakukan oleh seorang guru dalam menyampaikan materi pembelajaran kepada siswa. Bagi seorang guru evaluasi pembelajaran tidak dapat dipisahkan dari kegiatan mengajar, karena melalui evaluasi seorang guru akan mendapatkan informasi tentang pencapaian hasil belajar. Dengan evaluasi seorang guru mendapatkan informasi tentang materi yang telah ia gunakan, apakah dapat diterima oleh para siswanya, atau tidak.

Suatu evaluasi perlu memenuhi beberapa syarat sebelum diterapkan kepada siswa yang kemudian direfleksikan dalam bentuk tingkah laku. Syarat - syarat evaluasi baik yaitu 1) valid, 2) andal, 3) obyektif, 4) seimbang, 5) membedakan, 6) normal, 7) fair, 8) praktis.

Evaluasi selain untuk melengkapi penilaian, secara luas evaluasi dibatasi sebagai alat penilaian terhadap faktor-faktor penting suatu program termasuk situasi, kemampuan, pengetahuan, dan perkembangan tujuan.

Beragam teknik dapat dilakukan untuk mengumpulkan informasi tentang kemajuan peserta didik, baik yang berhubungan dengan proses belajar maupun hasil belajar. Teknik mengumpulkan informasi tersebut pada prinsipnya cara penilaian kemajuan belajar peserta didik berdasarkan standar kompetensi dan kompetensi dasar yang harus dicapai. penilaian kompetensi dasar dilakukan berdasarkan indikator-indikator pencapaian kompetensi yang memuat satu ranah atau lebih.

Teknik penilaian dalam proses belajar, Kunandar (2007)mengemukakan terdapat tujuh teknik penilaian sebagai berikut:1) Penilaian unjuk kerja atau perbuatan (Performance Test),2) Penilaian sikap, 3) Penilaian tertulis, 4) Penilaian proyek, 5) Penilaian produk, 6) Penilaian portofolio, 7 )Penilaian diri. 


\section{Metode Penelitian \\ Hipotesis penelitian hipotesis penelitian sebagai berikut:}

1. Terdapat pengaruh langsung positif penguasaan materi terhadap kualitas tes buatan guru .

2. Terdapat pengaruh langsung positif pengetahuan evaluasi terhadap kualitas tes buatan guru.

3. Terdapat pengaruh langsung positif penguasaan materi terhadap pengetahuan evaluasi.

Penelitian ini menggunakan metode survey yaitu suatu penelitian yang dilakukan untuk mengetahui gejala-gejala sosial pada objek yang diteliti. Dengan desain hubungan kausal serta bersifat deskriptif untuk menginterprestasikan apa yang terjadi, pendapat yang sedang berkembang, proses yang sedang terjadi atau efek dari salah satu kejadian yang sedang berkembang. Penelitian ini bersifat hubungan kausal karena berusaha menyelidiki pengaruh langsung antara beberapa variabel penelitian yaitu variabel pengetahuan evaluasi, variabel penguasaan materi dan variabel kualitas tes buatan guru. Dan untuk mengetahui pengaruh langsung dari variabel Residu yaitu variabel lain di luar variabel pengetahuan evaluasi dan penguasaan materi matematika, yang mempengaruhi variabel kualitas tes buatan guru dan telah teridentifikasi oleh teori tetapi tidak di masukan dalam model atau variabel lain di luar variabel pengetahuan evaluasi dan penguasaan materi, yang mempengaruhi variabel kualitas tes buatan guru tetapi belum teridentifikasi oleh teori, serta kemungkinan kekeliruan pengukuran (error of measuremen) dan komponen yang sifatnya tidak menentu (random component). Studi korelasional kausal ini akan menggunakan model Analisis Jalur (Path Analisis).

\section{POPULASI DAN TEKNIK PENGAMBILAN SAMPEL}

Populasi target dalam penelitian ini adalah seluruh guru di Kelompok Kerja Madrasah Tsanawiyah Negeri Kabupaten Tangerang. Sedangkan populasi terjangkau adalah guru matematika kelas VIII (Delapan) baik di Madrasah Tsanawiyah Negeri Maupun Madrasah Tsanawiyah Swasta yang berada di Kelompok Kerja Madrasah Negeri Rajeg Kabupaten Tangerang. Sampel merupakan representative dari masalah populasi yang diteliti. Karakter yang dimiliki populasi harus dimiliki pula oleh sampel. Dalam penelitian ini ditetapkan sampel di pilih secara teknik Multistages random sampling ${ }^{6}$. Artinya sampel yang berasal dari populasi yang berstrata atau bertingkat dimana tidak semua strata ditarik menjadi sampel yang diambil secara acak. Langkah-langkah pengambilan sampel adalah sebagai berikut: 1)Mendata seluruh madrasah yang berada di kelompok kerja madrasah rajeg, 2)Mengelompokan madrasah berdasarkan wilayah kecamatan, 3) Setiap kecamatan diambil secara acak madrasah yang akan dijadikan penelitian, 4)Sehingga terpilih secara acak 30 madrasah sebagai tempat penelitian untuk analisis. Dari hasil acak tersebut diperoleh jumlah madrasah 30, sehingga jumlah guru yang dijadikan sampel penelitian sebanyak 30 yang diambil dari setiap madrasah, khususnya guru bidang studi matematika kelas VIII ( delapan).

\section{INTRUMENT PENELITIAN}

Instrument yang dipergunakan dalam penelitian ini adalah berupa tes sebagai alat ukur mengetahui keadaan responden. Bentuk butir-butir kuesioner disusun dalam pertanyaan yang akan dijawab oleh responden. Instrument ini antara lain untuk mengukur variabel kualitas tes matematika buatan guru $\left(\mathrm{X}_{3}\right)$ sebagai variabel terikat (Eksogenus variable) dan variabel bebasnya (Endogenus variablel) adalah penguasaan materi matematika $\left(\mathrm{X}_{1}\right)$ dan pengetahuan evaluasi $\left(\mathrm{X}_{2}\right)$. Instrument yang disusun tersebut diuji validitasnya dan dihitung reliabilitasnya. Validitas instrument ini adalah merupakan validitas content atau isi. Hal ini dilakukan untuk menjamin kualitas instrument yang dimaksud, apabila dipergunakan untuk mengumpulkan data dalam penelitian.

\section{UJI COBA INTRUMENT}

Pra uji coba mengetahui validitas tes penguasaan materi matematika $\left(X_{1}\right)$ dan tes pengetahuan evaluasi $\left(X_{2}\right)$, dilakukan validitas masing - masing oleh 2 (dua) orang penilai yang se-profesi, berpedoman pada kisi - kisi yang telah dibuat. Serta didiskusikan kepada pembimbing dan dinyatakan bahwa kedua intrumen tes tersebut telah memenuhi syarat untuk diujicobakan setelah dilakukan beberapa perbaikan. Uji coba intrumen dilaksanakan pada tanggal terhadap 30 responden yang diambil diluar responden penelitian. Uji coba intrumen dilaksanakan terhadap variabel penguasaan materi matematika $\left(X_{1}\right)$ dan pengetahuan evaluasi $\left(X_{2}\right)$, sedangkan kualitas tes matematika buatan guru $\left(X_{3}\right)$ tidak diujicobakan karena ingin melihat kemampuan guru yang sebenarnya dalam membuat tes berdasarkan dokumen yang yang dimilikinya. Tujuan ujicoba adalah untuk mengetahui kelayakan intrumen penelitian yang akan digunakan saat pelaksanaan penelitian. 


\section{TEKNIK PENGUMPULAN DATA}

Dalam pengumpulan data penelitian digunakan teknik tes dan dokumenter. Teknik tes digunakan untuk menjaring data penguasaan materi matematika $\left(\mathrm{X}_{1}\right)$ dan pengetahuan evaluasi $\left(\mathrm{X}_{2}\right)$ sedangkan tes kualitas tes matematika buatan guru $\left(\mathrm{X}_{3}\right)$ digunakan teknik dokumenter, yaitu dengan cara mengumpulkan tes matematika buatan guru, lembar jawaban siswa. Penguasaan materi matematika dengan mengumpulkan seperangkat silabus dan rencana pelaksanaan pembelajaran matematika Madrasah Tsanawiyah kelas delapan semester 1, yang merupakan acuan guru dalam menyusun tes matematika.

\section{Pembahasan}

Skor kualitas tes matematika buatan guru di peroleh dari gabungan antara skor validitas isi atau conten validity, validitas item dan reliabilitas yang skornya dikonversi melalui t-Skor. Untuk skor validitas isi diperoleh dari rata-rata hasil tim penilai yang beranggotakan 3 orang, sedangkan skor reliabilitas dan validitas di peroleh dari hasil perhitungan analisis tes matematika yang di buat oleh guru dan telah di gunakan dalam evaluasi pembelajaran matematika dengan menggunakan Program Analisis Butir. Selanjutnya dilakukan konversi baik skor validitas isi,validitas butir,dan reliabilitas dengan skor-t, dari hasil perhitungan, setelah di bulatkan diperoleh skor tertinggi yang dapat di capai oleh responden $=67$, skor terendah $=35$, skor rata-rata $($ mean $)=50,133$, median 50,5 , modus $=$ 50 , dan standar deviasi $=6,85$.

Skor penguasaan materi matematika di peroleh dari tes penilaian penguasaan materi matematika yang di jawab dengan pertanyaan terhadap guru Madrasah Tsanawiyah. Skor tertinggi $=27$ dan skor terendah $=20$ skor rata-rata $($ mean $)=$ 23,76 Median $=24$ modus $=25$, dan standar deviasi $=2,71$.

Skor pengetahuan evaluasi diperoleh dari tes penilaian pengetahuan evaluasi yang di jawab dengan pertanyaan terhadap guru Madrasah Tsanawiyah. Skor tertinggi $=27$ dan skor terendah $=24$ skor rata-rata $($ mean $)=25,43$ Median $=25$ modus $=25$, dan standar deviasi $=0,843$.

\section{Kesimpulan}

Pertama, Terdapat pengaruh langsung penguasaan materi matematika terhadap kualitas tes matematika buatan guru. Hal ini bermakna kualitas tes matematika buatan guru dipengaruhi secara langsung oleh penguasaan materi matematika apabila penguasaan materi matematika ditingkatkan maka kualitas tes matematika buatan guru juga akan meningkat.

Kedua, Terdapat pengaruh langsung pengetahuan evaluasi terhadap kualitas tes matematika buatan guru. Hal ini bermakna kualitas tes matematika buatan guru dipengaruhi secara langsung oleh pengetahuan evaluasi, apabila pengetahuan evaluasi ditingkatkan maka kualitas tes matematika buatan guru juga akan meningkat.

Ketiga, Terdapat pengaruh langsung penguasaan materi matematika terhadap pengetahuan evaluasi. Hal ini mengandung makna pengetahuan evaluasi dipengaruhi secara langsung oleh penguasaan materi matematika, apabila penguasaan materi matematika ditingkatkan maka pengetahuan evaluasi juga akan meningkat.

Memperhatikan ketiga kesimpulan diatas dapat diketahui bahwa penguasaan materi matematika dan pengetahuan evaluasi memiliki kaitan erat dengan kualitas tes matematika buatan guru. Dengan kata lain kualitas tes matematika buatan guru dapat ditentukan oleh penguasaan materi matematika dan pengetahuan evaluasi. Hal ini diketahui dari pengaruh masing-masing variabel eksogen seperti berikut:

1. Penguasaan materi matematika memberikan pengaruh terhadap kualitas tes matematika buatan guru sebesar $68 \%$.

2. Pengetahuan evaluasi memberikan pengaruh terhadap kualitas tes matematika buatan guru sebesar $87,7 \%$.

3. Penguasaan materi matematika memberi pengaruh terhadap pengetahuan evaluasi sebesar $51,9 \%$.

\section{Saran}

Pertama, untuk meningkatkan kualitas tes matematika buatan guru, guru dipandang perlu untuk meningkatkan penguasaan materi matematika dan pengetahuan evaluasi. Sebab dengan demikian adanya peningkatkan penguasaan materi matematika dan pengetahuan evaluasi, maka akan muncul kesadaran untuk lebih tekun lagi dalam melatih diri membuat soal-soal, melakukan analisis terhadap soal-soal yang telah digunakan untuk memanfaatkan secara optimal musyawarah guru mata pelajaran (MGMP).

Kedua, untuk lembaga tinggi yang menghasilkan calon tenaga kependidikan seperti Fakultas pendidikan, khususnya pencetak guru ditingkat Madrasah Tsanawiyah diharapkan memberikan tekanan perkulihaan pada penyelenggaraan evaluasi pendidikan.

Ketiga, bagi pihak kepala sekolah, pengawas, dan pemerintah dalam hal ini Kementerian Agama khususnya Kabupaten Tangerang, agar mengupayakan untuk memberikan pembinaan profesi, misalnya menyelenggarakan penataran matematika atau pelatihan penyusuna soal dan pemuatan soal tes kepada guru-guru secara terencana guna 
meningkatkan prestasi siswa khususnya dalam mata pelajaran matematika dan umunnya semua mata pelajaran yang diajarkan di Madrasah Tsanawiyah, juga memperbaiki pengetahuan evaluasi melalui pelatihan dan pendidikan serta pembinaan kinerja jabatan guru yang didukung oleh kepada madrasah dan pengawas dari Kementerian Agama Kabupaten Tangerang.

Keempat, bagi para peneliti dalam bidang pendidikan pada umumnya diharapkan dapat melakukan pengamatan dan penelitian lanjutan, sebagai usaha untuk menemukan sejumlah factor lain yang mengarah pada peningkatan pretasi siswa dalam matematika. Hasil temuan ini diharapkan dapat dijadikan sebagai dasar untuk penentuan kebijakan di masa mendatang bagi pihak - pihak yang berwenang. Dengan meningkatkan prestasi siswa dalam matematika diharapkan dapat diperoleh informasi yang tepat dan akurat untuk meningkatkan kualitas hasil belajar siswa yang bertujuannya adalah peningkatkan mutu pendidikan nasional.

Kelima, bagi praktisi, dan pemerhati pendidikan, hendaknya dapat menjadi hasil temuan ini sebagai dasar yang dapat dikembangkan untuk mengangkat isu - isu pendidikan secara konsisten sehingga terjadi pemihakan yang tinggi oleh pemerintah terhadap bidang pendidikan dinegara Indonesia yang tercinta ini. Amin.

\section{Daftar Pustaka}

Ahiri, J. 2008. Teknik Penilaian Kelas Dalam Pembelajaran. Cet ke-1, Jakarta: UHAMKA PRESS.

Arikunto, S. 2009. Dasar-Dasar Evaluasi Pendidikan. Cet ke-9, Jakarta: Bumi Aksara.

Ary Donald. 1982. Introduction to Research in Education. Diterjemahkan oleh Arief Furchan. Penelitian Dalam Bidang Pendidikan. Surabaya : Usaha Nasional.

Allen J. Mary dan Wendy M. Yen. 1979. Introduction to Measurement and Evaluation in Psyhology and Education. California. Book Cole Publishing Company.

Anastasi Anne. 1976. Psychological Testing. London : Macmillan Publishing Co. Inc.

Athanasou, J \& Lamprianou, I. 2002. A Teacher's Guide To Assessment. Australia: Social Science Press.

Azyumardi dan Tim Penyusun. 2002. Ensiklopedi Islam Fas-Kal 2. Cet-10, Jakarta : Ichtiar Baru Van Hoeve.

Bambang P dan Lina P,J. 2006. Metode Penelitian Kuantitatif. Jakarta : . PT. RajaGrafindo Persada.

Budi Kuncoro. 2010. File:///D:/file\%20down/mutu-tes-motivasi-sikap.html

Calengosi S. James. 1991. Evaluating Classroom Intruction. New York : Longman

Chocker, L and Algina, J. 1986. Introduction To Classical And Modern Test Theory. University Of Florida :Holt, Rinehart And Winston, INC.

Cronbach L.J. 1984. Essential of Physiological, Testing . New York: Horner \& Row Publisher.

Diknas. 2009. Penulisan Butir Soal. Internet.

Direktorat Pendidikan Madrasah Departemen Agama. 2007. Sertifikasi Guru Dalam Jabatan. Jakarta : Direktorat Pendidikan Madrasah Departemen Agama.

Djaali dan Kadir. 2008. Metodologi Penelitian. Jakarta :Program Magister Penelitian dan Evaluasi, Universitas Negeri Jakarja.

Djaali dan Pudji M. 2008. Pengukuran Dalam Bidang pendidikan. Jakarta: PT. Grasindo.

Djamarah Bahri S. 1994. Prestasi Belajar Kompetensi Guru. Surabaya : Usaha Nasional.

Faizah. 2001. Analisis Tes Matematika : Studi Korelasional Antara Penguasaan Matematika Guru dan Sikap Guru Terhadap Evaluasi dengan Kualitas Tes Matematika Buatan Guru. Jakarta : Tesis PPS UHAMKA. 
Gaffar Fakry M. 1987. Perencanaan Pendidikan ; Teori dan Metodologi. Jakarta : Pengembangan LPTK Dikkti.

Gronlund N.E. 1993. How to Make Achievement Tes and Assessment. Massachussets: Allyn and Bacon.

Hayat Bahrul. 1994. Manual Item and Test Analisis. Jakarta: Dikbud.

Jurnal Penelitian dan Manajemen Pendidikan. 2006. Jakarta: Program Pasca Sarjana Universitas Muhammadiyah Prof. DR. HAMKA.

Kadir. 2010. Statistika(untuk penelitian ilmu - ilmu sosial). Jakarta: Rosemata Sampurna.

Kerlinger Fred N. 1998. Azas-Azas Penelitian Behavior. Diterjemahkan oleh Landunf R. Simatupang. Yogyakarta : Gajahmada University Press.

Kunandar. 2007. Guru professional Implementasi Kurikulum Tingkat Satuan Pendidikan ( KTSP ) dan Persiapan Menghadapi Sertifikasi Guru. Edisi I, Jakarta : PT. RajaGrafindo Persada.

Klenowski Val. 2004. Development Portofolis For Learning and Assessment Processes and Principles. London and New york: RoutledgeFalmer Taylor \& Francis Group.

LN Yusuf, S. 2004. Psikologi Perkembangan Anak \& Remaja. Cet ke-4, Bandung : PT. Remaja Rosdakarya.

Mar'at. 1980. Sikap Manusia Perubahan Serta Pengukurannya. Jakarta : Ghalia.

Meliono, Irmayanti, dkk. 2007. MPKT Modul 1. Jakarta : Lembaga Penelitian FEUI. File://D:/file\%20down /pengetahuan\%201.htm.

Mehrens William A dan Lehmann Irvin J. 1973. Measurements and Evaluation in Education and Psychology. New york : Rinehart and Winston Inc.

Moleong, L. J. 2005. Metodologi Penelitian Kualitatif. Cet Ke-21, Bandung : PT. Remaja RosdaKarya.

Morris Lynn Lyons dan Gibbon Carol Taylor Fitz. 1986. How to Measure Achievement. London : Sage Publications.

Morgan Clifford T. 1986. Introduction to Psychology. New York : MC Graw Hill Book Company.

Muhammad, F \& Djaali. 2005. Metodolodi penelitian Sosial. Edisi Revisi, Jakarta : Restu Agung.

Murwarni Santosa. 2007. Pengantar Evaluasi Pendidikan. Cet ke-1, Jakarta :UHAMKA PRESS

Statistik Terapan Teknik Analisis Data. Jakarta : Program Pasca Sarjana Universitas Muhammadiyah Prof. DR. HAMKA.

2008. Model Proposal : Penelitian Eksperiment, Penelitian Survey, Penelitian Survey Kausal dilengkapi dengan Path Analisysis ( Analisis Jalur ). Jakarta : Program Pasca Sarjana Universitas Muhammadiyah Prof. DR. HAMKA.

Prof. DR. HAMKA.

2008. Metodologi Penelitian Ilmiah. Jakarta : Program Pasca Sarjana Universitas Muhammadiyah

.2009. Suplemen Statistika. Jakarta : Program Pasca Sarjana Universitas Muhammadiyah Prof.

DR. HAMKA.

Mudjijo. 1985. Tes Hasil Belajar. Jakarta : Bumi Aksara.

Muhidin Ali Sambas dan Abdurahman Maman. 2007. Analisis Korelasi, Regresi, dan jalur Dalam Penelitian. Bandung : Pustaka Setia. 
Mulyasa. 2005. Menjadi Guru Profesional. Bandung : Remaja Rosdakarya.

Nasution S. 1982. Didaktik Azas-Azas Mengajar. Bandung : Jemmars.

Nawawi Hadari. 1985. Organisasi Sekolah dan Pengelolaan Kelas Lembaga Pendidika. Jakarta: Gunung Agung.

Popham, W.J. 1995. Classroom Assessment What Teachers Need To Know. United States America : Allyn and Bacon.

Prasetyo, B dan Jannah, L.M. 2006. Metode Penelitian Kuantitatif. Edisi ke-1, Jakarta : PT. RajaGrafindo Persada.

Purwanto Ngalim. 1980. Ilmu Pendidikan Teoritis dan Praktis. Jakarta: Aksara

Ridwan dan Kuncoro Achmad E. 2007. Analisis Jalur ( Path Analysis). Cetakan Pertama. Bandung : Alfabeta.

Riduwan. 2009. Metode dan Teknik Menyusun Proposal Penelitian. Bandung : Alfabeta.

Rosyidi Imron. 2004. Profesi Kependidikan . Cet ke-4, Jakarta. WSP Group Jakarta.

Russefendi. 1988. Pengajaran Matematika Modern Untuk Orang tua Murid, Guru dan SPG. Bandung: Tarsito.

Sardiman A.M. 2000. Interaksi dan Motivasi Belajar Mengajar. Jakarta: PT. Raja Grafindo Perkasa.

Setiadi Hari. 1999. Bank Soal Yang Dikalibrasi dengan Konsep IRT Memecahkan Masalah Permasalahanpermasalahan Pada Ujian-Ujian Sistematik Yang diadakan Periode-periode Tertentu. Jakarta. Dikbud.

Kegunaan dan Keunggulan Mendesain Perangkat Tes Dengan Menggunakan Konsep IRT. Bulletin. Pengujian dan Penilaian Pendidikan Jakarta. Depdikbud.

Singarimbun, M., 1986. Pedoman Praktis Membuat Penyusunan Penelitian. Cet ke-2, Jakarta, Ghalia Indonesia.

Sugiono. 2008. Metode Penelitian pendidikan Pendekatan Kuantitatif, Kualitatif, dan R\&D. Cet ke-5, Bandung, Alfabeta.

Sudiono Anas. 1998. Pengantar Evaluasi Pendidikan. Jakarta PT. Raja Gravindo Persada.

Santoso Budi. 2007. Panduan Belajar Teori Tes. Jakarta, Jurusan Penelitian dan Evaluasi Pendidikan Program Pasca Sarjana Universitas Negeri Jakarta.

Somantri Ating dan Muhidin A. S. 2006. Aplikasi Statistika Dalam Penelitian. Bandung. CV Pustaka Setia

Subana, Rahadi, M \& Sudrajat. 2005. Statistik Pendidikan. Cet ke-2, Bandung, Pustaka Setia.

Sudijono Anas. 2005. Pengantar Statistik Pendidikan. Cet ke-15, Jakarta, RajaGrafindo Persada.

Sudarsono. 2001. Readers-3 Kumpulan Artikel \& Makalah Metodologi Penelitian Bagi Mahasiswa Program Pasca Sarjana. Program Pasca Sarjana UNY.

Sugandi, E \& Sugiarto. 1994. Rancangan Percobaan Teori dan aplikasi. Cet ke-1, Yogyakarta, Andi Offset Yogyakarta.

Sugiono. 2008. Metode Penelitian pendidikan Pendekatan Kuantitatif, Kualitatif, dan R\&D. Cet ke-5, Bandung, Alfabeta.

Suherman Uman. 2002. Psikologi Pendidikan Membangun Interaksi Pembelajaran Optimal. Publikasi Jurusan Psikologi Pendidikan dan Bimbingan Fakultas Ilmu Pendidikan Universitas Pendidikan Indonesia.

Suherman Erman. 2002. Common Texbook Strategi Pembelajaran Matematika Kontemporer. Jica UPI, Bandung. 
Jurnal Inovasi Pendidikan MH. Thamrin , 1; Februari 2017

Sujana. 2003. Teknik Analisis Regresi Dan Korelasi. Bandung. Tarsito

Sukardi, H.M. 2008. Evaluasi Pendidikan Prinsip \& Operasionalnya. Cet ke-1, Jakarta, Bumi Aksara.

Tayibnapis Yusup F. 2008. Evaluasi Program dan Intrument Evaluasi. Jakarta : PT. Rineka Cipta.

Tola Burhanudin. 2009. Modul Assessment Based On Class. Jakarta.

Modul Penilaian Berbasis Kelas. Jakarta.

Trianto. 2007. Model-Model Pembelajaran Inovatif Berorientasi Kontruktivistik Konsep, Landasan teoritis-Praktis dan Implementasi. Cet-1, Jakrta, Prestasi Pustaka Publisher.

Tim Penyusun Tesis dan Desertasi. 2009. Pedoman Tesis dan Desertasi. Jakarta, Program Pasca Sarjana Universitas Muhammadiyah Prof. DR. HAMKA, UHAMKA Press.

Usman M.U. 2002. Menjadi guru professional. Bandung : PT. Remaja Rosdakarya.

Uyanto Stanislaus, S. 2009. Pedoman Analisi Data dengan SPSS. Edisi 3, Jakarta. Graha Ilmu.

Umar J. 1991. Pengantar Penilaian Pendidikan : Sekelumit Tentang Teori Tes Prestasi Belajar. Jakarta : Pusisjian.

Wayan, N dan P.P.N Sumartana. 1986. Evaluasi Pendidikan. Cet ke-4, Surabaya. Usaha Nasional

Waluyo. 1987. Materi Pokok Penilaian Pencapaian Hasil Belajar. Jakarta: Karunika.

Wirawan. 2008. Profesi dan Standar Evaluasi. Cet ke-3, Jakarta. Yayasan Bangun Indonesia \& UHAMKA PRESS.Bandung : Rosdakarya.

W Gulo. 2004. Strategi Belajar Mengajar. Cet ke-2, Jakarta. PT. Gramedia Widiarsarana Indonesia 